\title{
Spatial and temporal variations of evapotranspiration, groundwater and precipitation in Amazonia
}

\author{
Juan Zhang ${ }^{1}$, Jie Niu ${ }^{1}$, Chaopeng Shen ${ }^{2}$, John Melack ${ }^{3}$, Jin Zhang ${ }^{1}$, Han Qiu ${ }^{4}$, Bill Hu${ }^{1}$, \\ and William Riley ${ }^{5}$ \\ ${ }^{1}$ Jinan University \\ ${ }^{2}$ Pennsylvania State University \\ ${ }^{3}$ University of California Santa Barbara \\ ${ }^{4}$ Pacific Northwest National Laboratory \\ ${ }^{5}$ Lawrence Berkeley National Laboratory
}

August 3, 2020

\begin{abstract}
The relationships and seasonal-to-annual variations among evapotranspiration (ET), precipitation (P), and groundwater dynamics (total water storage anomaly, TWSA) are complex across the Amazon basin, especially the water and energy limitation mechanism for ET. To analyze how ET is controlled by P and TWSA, we used wavelet coherence analysis to investigate the effects of $\mathrm{P}$ and TWSA on ET at sub-basin, kilometer, regional, and whole basin scales in the Amazon basin. The Amazon-scale averaged ET has strong correlations with P and TWSA at the annual periodicity. The phase lag between ET and P ( _(ET-P)) is $\sim 1$ to $\sim 4$ months, and between ET and TWSA ( _(ET-TWSA)) is $\sim 3$ to $\sim 7$ months. The phase pattern has a south-north divide due to the significant variation in climatic conditions. The correlation between _(ET-P) and _(ET-TWSA) is affected by the aridity index, of each sub-basin, as determined using the Budyko framework at the sub-basin level. In the southeast Amazon during a drought year (e.g., 2010), both phases decreased, while in the subsequent years, _(ET-TWSA) increased. The area of places where ET is limited by water continues to decrease over time in the southern Amazon basin. These results suggest immediate strong groundwater subsidy to ET in the following dry years in the water-limited area of Amazon. The water storage has more control on ET in the southeast but little influence in the north and southwest after a drought. The areas of ET limited by energy or water are switched due to the variability in weather conditions.
\end{abstract}

Spatial and temporal variations of evapotranspiration, groundwater and precipitation in Amazonia

Juan Zhang ${ }^{1}$, Jie Niu ${ }^{1}$, Chaopeng Shen ${ }^{2}$, John M. Melack ${ }^{3}$, Jin Zhang ${ }^{1}$, Han Qiu ${ }^{4}$, Bill X. Hu ${ }^{1}$, and William J. Riley ${ }^{5}$

${ }^{1}$ Institute of Groundwater and Earth Science, Jinan University, Guangzhou 510632, China

${ }^{2}$ Civil and Environmental Engineering, Pennsylvania State University, PA

${ }^{3}$ Earth Research Institute, University of California, Santa Barbara, CA

${ }^{4}$ Joint Global Change Research Institute, Pacific Northwest National Lab, College Park, MD 20740, USA

${ }^{5}$ Earth Sciences Division, Lawrence Berkeley National Lab, Berkeley, CA

Correspondence to: J. Niu, jniu@jnu.edu.cn

\section{Abstract}


The relationships and seasonal-to-annual variations among evapotranspiration $(E T)$, precipitation $(P)$, and groundwater dynamics (total water storage anomaly, TWSA ) are complex across the Amazon basin, especially the water and energy limitation mechanism for $E T$. To analyze how $E T$ is controlled by $P$ and $T W S A$, we used wavelet coherence analysis to investigate the effects of $P$ and TWSA onET at sub-basin, kilometer, regional, and whole basin scales in the Amazon basin. The Amazon-scale averaged ET has strong correlations with $P$ and TWSA at the annual periodicity. The phase lag between $E T$ and $P\left(\phi_{E T-P}\right)$ is $\sim 1$ to $\sim 4$ months, and between ETand TWSA $\left(\phi_{E T-T W S A}\right)$ is $\sim 3$ to $\sim 7$ months. The phase pattern has a southnorth divide due to the significant variation in climatic conditions. The correlation between $\phi_{E T-P}$ and $\phi_{E T-T W S A}$ is affected by the aridity index, of each sub-basin, as determined using the Budyko framework at the sub-basin level. In the southeast Amazon during a drought year (e.g., 2010), both phases decreased, while in the subsequent years, $\phi_{E T-T W S A}$ increased. The area of places where ET is limited by water continues to decrease over time in the southern Amazon basin. These results suggest immediate strong groundwater subsidy to $E T$ in the following dry years in the water-limited area of Amazon. The water storage has more control on $E T$ in the southeast but little influence in the north and southwest after a drought. The areas of $E T$ limited by energy or water are switched due to the variability in weather conditions.

Running head: Evapotranspiration, groundwater and precipitation variation in Amazon

Keywords: Evapotranspiration (ET ), Wavelet coherence, Amazon basin, Phase lag, Budyko framework

\section{Introduction}

Climate change is accompanied by increasing variability in seasonal rainfall (Feng et al., 2013) and alters rainfall regimes, where water availability and timing are key factors controlling primary productivity (Briggs \& Knapp, 1995; Weltzin et al., 2003; Huxman et al., 2004) and the phenology of growth and reproduction (Dirzo et al., 2011; Walther et al., 2002). Evapotranspiration (ET ) links regional climate and forest function and plays an important role in the hydrological cycle. It is also an internal connection with $\mathrm{CO}_{2}$ flux during the transpiration process and an indicator for ecosystem function. It is broadly known that the Amazon basin transfers large amounts of water from the land surface to the atmosphere by $E T$ every day, which has a huge impact on the global energy budget (Christoffersen et al., 2014; Hasler \& Avissar, 2006; RestrepoCoupe et al., 2016). Therefore, any impact on the ET over the Amazon tropical forest may affect the global carbon cycle and provide further feedback to climate change. Nonetheless, the spatio-temporal variation of $E T$ across the Amazon basin, as well as the relative contributions of multiple drivers to this process, are still uncertain. Thus, assessing the factors controlling ET in the Amazon basin is fundamentally important and largely depends on how tropical vegetation processes available energy and water (Nepstad et al., 1994; Saleska et al., 2003).

Controls of ET across the Amazon basin vary. Based on observations and model syntheses, the response of forest cover to seasonal disparities in both water availability and solar radiation can reduce drought susceptibility by temporally adjusting net leaf flush (Jones et al., 2014). Wagner et al. (2016) found that the seasonal variation of canopy photosynthetic capacity is positively correlated with precipitation $(P)$ (water-limited forests) when rainfall is less than $\sim 2000 \mathrm{~mm} \mathrm{yr}^{-1}$, and negatively correlated with radiation (light-limited forests). Costa et al. (2010) concluded that ET in the dry season is larger than that in the wet season and that surface net radiation is the main controller of ET in wet equatorial sites. Some models (Baker et al., 2008; da Rocha et al., 2009; Kleidon \& Heimann, 2000; Werth \& Avissar, 2004) predict water-limited $E T$ seasonality that resembles $P$ variations. Considering the large scale of previous studies, the evaluation of $E T$ drivers has not been conclusive in some cases, or only analyzed for the whole Amazon basin. Malhi et al. (2002) were the first to measure a full annual trend of latent heat flux for the Cuieiras forest close to Manaus. Their regression results indicate that water limitation and stomatal control were the main factors driving seasonal ET . Nemani et al. (2003) concluded that light is more limiting than water for tropical forest productivity, consistent with greening of Amazon forests during the dry season from satellite data (Brando et al., 2010; Doughty \& Goulden, 2008; Huete et al., 2006; Myneni et al., 2007; Samanta et al., 2012). By evaluating potential mechanisms for the seasonal green-up phenomenon, Morton et al. (2014) found that the light-limited net primary production in Amazon forest and enhanced forest growth during 
drought conditions are influenced by the stability of Amazon forest structure and reflectance over seasonal timescales. Recent studies based on eddy flux measurements indicate seasonal ET is driven by radiation, rather than water availability, in the Amazon (da Rocha et al., 2009; Juárez et al., 2007) and across the tropics (Fisher et al., 2009). Maeda et al. (2017) suggested that both annual mean and seasonality of ET are driven by a combination of energy and water availability, as rainfall or radiation alone could not explain $E T$ patterns. This led to continued controversy regarding the seasonality of $E T$ and its control. Therefore, more detailed studies are needed to explore the factor driving $E T$ (i.e., radiation or water availability).

The modeling results from Verbeeck et al. (2011) show that forests in some regions of the Amazon maintain high transpiration during the dry season. Therefore, the flux of ET will also be changed by various external conditions, resulting in great uncertainty for ETmeasurements that are sparse and often indirect due to the limited spatial coverage and the complex plant components (Culf et al., 2008). Moreover, there are systematic biases of hydrologic and carbon fluxes and responses in Earth system models. For example, Tang et al. (2015) found that ET predicted using CLM4.5 at the Tapajos forest site in the Amazon basin compares poorly and is out of phase with MODIS data (MOD16A2). The latest MOD16 global ET product agrees well with measurements from Amazon tropics eddy flux towers ( $\mathrm{Mu}$ et al., 2011), and shows higher ET in the dry season and lower $E T$ in the wet season. On the one hand, ET includes contributions from the evaporation of the ground or other wet surfaces, as well as transpiration flux from plants. Thus, ET reflects aspects of the aspiration functioning of plants (Swann et al., 2017) and is largely affected by precipitation, as the vegetation canopy of the Amazon rainforest is highly sensitive to changes in precipitation patterns. Reduction in rainfall has diminished vegetation greenness, which coincides with the decline in terrestrial water storage (Hilker et al., 2014). This pattern is supported by severe drought suppressed photosynthesis (Doughty et al., 2015). On the other hand, groundwater has a strong influence on hydrologic responses in the Amazon (Tomasella et al., 2010). Previous empirical studies indicate that errors result if groundwater is not included in hydrologic balances (Leopoldo et al., 1995; Lesack, 1993). Several modeling studies have also concluded that surface runoff is rare and groundwater plays a key role in Amazon hydrology (Hodnett et al., 1997b, 1997a; Leopoldo et al., 1995; Miguez-Macho \& Fan, 2012a), and groundwater has significant influence on soil moisture and ET (Miguez-Macho \& Fan, 2012b). Our recent analysis with a three-dimensional hydrologic model applied to Amazon watersheds (Niu et al., 2017) demonstrated that lateral fluxes, especially groundwater flows, have a large impact on hydrologic responses.

To detect and analyze oscillations of different hydrologic components on a given scale, wavelet coherence analysis qualitatively estimates the temporal evolution of the degree of linearity of the relationship between two signals (Labat, 2005). Wavelet spectral and correlation analyses have been applied widely in previous studies to identify the annual periodicity of the hydrologic and climate fluxes and detect their long-term trends (Andreo et al., 2006); to detect potential flood triggering conditions (Schaefli et al., 2007); and to extract significant information and the characteristic time scale of the dominant hydrologic processes (Molénat et al., 1999; Zhang et al., 2016). The method has also been applied to Amazon River monthly discharges to suggest physical explanations for time-scale dependent relationships (Labat et al., 2005). To the best of our knowledge, due to the scarcity of observations, especially of water table depth, no previous studies using wavelet spectral has analyzed the relationships between $P$ and $E T$, or groundwater and $E T$, in the Amazon. The phase difference of wavelet analysis can obtain the dynamic correlation among hydrological components, and its application is relatively rare. In addition, the Budyko curve framework is a classic empirical approach to analyze annual hydrological budgets and their inter-annual variability (Bukydo, 1974). The Budyko framework has been used to evaluate the inter-annual variability of annual water balances (Yang et al., 2007; Wang, 2012). A recent study found that the errors between observations and the traditional Budyko curve could be reduced if the equation was corrected using information extracted from the Gravity Recovery and Climate Experiment (GRACE) terrestrial water storage anomalies (TWSA ) (Fang et al., 2016).

In this paper, we explore the relationships and seasonal-to-annual variations among $P, E T$, and TWSA across the Amazon basin using wavelet analysis. By analyzing the phase differences among $P(T W S A)$ and $E T$, we can explore the interaction between $E T$ fluxes and rainfall (groundwater) at different scales (for 
sub-basins, the individual grid cells, different climatic zones, and averaged for the whole Amazon basin), including the effects of drought. The purpose is to dynamically analyze the main factors controlling ET across the Amazon basin. We also apply the Budyko framework to evaluate the annual hydrological budgets in sub-basins of the Amazon and analyze the degree of radiation and rainfall limitation, as well as their interactive effects on $E T$. With these tools we address the following hypotheses: (1) in years with sufficient $P, E T$ is energy limited, while during drought years, plants have sufficient water supply from groundwater to maintain photosynthesis andET compared to normal years; (2) after a drought year, the groundwater system recovers, and the phases between $E T$ and $P$, and between $E T$ and $T W S A$, reflect this recovery; and (3) the above two hypotheses vary spatially and the spatial heterogeneity of the water-energy balance account for their spatial variation. Hypotheses (1) and (2) were addressed using wavelet coherence phase analysis for the whole Amazon (Section 3.1), sub-basins (Section 3.2), and sub-regions (Section 3.5). The analyses at different scales (from Section 3.2 to Section 3.5) help address hypothesis (3), specifically, applying the wavelet coherence phase for analyzing the individual grid cells and the Bydyko framework for analyzing each sub-basin.

\section{Methods}

\subsection{Data Sources}

The Tropical Rainfall Measuring Mission (TRMM, available from NASA, http://trmm.gsfc.nasa.gov/) 3B42 V7 daily data with 0.25 -degree spatial resolution were used for $P$. MODIS 16 monthly data (MODIS 16A2; Mu et al., 2007) were used for $E T$ (http://www.ntsg.umt.edu/project/mod16) at $1 \mathrm{~km}$ resolution for the global vegetated land areas and cover the period 2002 to 2013. The latest ET product (Mu et al., 2011) implements the improved $E T$ algorithm in $\mathrm{Mu}$ et al. (2007) and agrees well with measurements from 46 eddy flux towers, including two towers in the Amazon basin. The most recent release of the spherical harmonics GRACETWSA (RL05) was downloaded from the Jet Propulsion Laboratory (available at http://grace.jpl.nasa.gov/). This distributed GRACE product has been "destriped" and smoothed using a $300 \mathrm{~km}$ wide Gaussian filter to minimize north-south stripes, and is appropriate for land hydrology applications (Landerer \& Swenson, 2012; Swenson \& Wahr, 2006). The resolution of GRACE and TWSA data are 1-degree.

The sub-basin delineation map applied here was obtained from a topography-independent analysis method (Mayorga et al., 2005) using the vector river network from the Digital Chart of the World (DCW, Danko, 1992). The map includes the sub-basin boundaries of the major tributaries to the main stem of the Amazon River (http://daac.ornl.gov/LBA/guides/CD06_CAMREX.html).

\subsection{Wavelet Analysis}

The concepts of wavelet analysis have been reviewed in previous publications (Daubechies, 1990; Labat, 2005; Torrence \& Comp, 1998). Briefly, similar to Fourier analysis, wavelet analysis extracts frequency information (called scales) from time series. Wavelet analysis also reveals the timing of the features. For this work, we adopted the algorithm of wavelet transform from Torrence and Compo (1998). The wavelet power spectrum is then defined as $\left|W_{n}(s)\right|^{2}$ and the phase angle isatan $2\left(\frac{\operatorname{Imag}\left\{W_{n}(s)\right\}}{\operatorname{Real}\left\{W_{n}(s)\right\}}\right)$, where atan2 is the four-quadrant inverse tangent function, Real $\left\{W_{n}(s)\right\}$ is the real part of the continuous wavelet transform $W_{n}(s)$, andImag $\left\{W_{n}(s)\right\}$ denotes the imaginary part. The wavelet power spectrum provides insight into the temporal-scale variability of the time series.

The global wavelet spectrum is defined as the time-averaged wavelet spectrum over all the local wavelet spectra:

$\mathbf{W}^{2}(\mathbf{s})=\frac{1}{\mathbf{N}} \sum_{\mathbf{n}=0}^{\mathrm{N}-1}\left|\mathbf{W}_{\mathbf{n}}(\mathbf{s})\right|^{2}$. (1)

where $N$ is the number of points in the time series.

Given two time series $X$ and $Y$, with wavelet transforms $W_{n}^{X}(s)$ and $W_{n}^{Y}(s)$, the cross-wavelet spectrum is 
defined as:

$\mathbf{W}_{\mathbf{n}}^{\mathrm{XY}}(\mathbf{s})=\mathbf{W}_{\mathbf{n}}^{\mathbf{X}}(\mathbf{s}) \mathbf{W}_{\mathbf{n}}^{\mathbf{Y}^{*}}(\mathbf{s})(2)$

where $W_{n}^{Y^{*}}(s)$ is the complex conjugate of $W_{n}^{Y}(s)$. The cross-wavelet power is $\left|W_{n}^{\mathrm{XY}}(s)\right|$, and indicates covariance between the time series at all time scales. The wavelet coherence is defined as the square of the cross-spectrum, $\left|W_{n}^{\mathrm{XY}}(s)\right|^{2}$ normalized by the individual power spectra. The wavelet coherence ranges between 0 and 1 and provides a qualitative estimator of the temporal evolution of the degree of linearity of the relationship between two signals on a given temporal scale. The coherence phase is therefore defined $\operatorname{asatan}\left(\frac{\operatorname{Imag}\left\{W_{n}^{\mathrm{XY}}(s)\right\}}{\operatorname{Real}\left\{W_{n}^{\mathrm{XY}}(s)\right\}}\right)$.

To derive the phase, $\phi$, the difference in timing between two time series at their maximum power spectrum, we multiplied the coherence phase in proportion to $2 \pi$ by their coherent period at their maximum cross wavelet power spectrum band:

$\phi=\operatorname{atan2}\left(\frac{\operatorname{Imag}\left\{\mathbf{W}_{\mathbf{n}}^{\mathrm{XY}}\left(\mathbf{s}_{\max }\right)\right\}}{\operatorname{Real}\left\{\mathbf{W}_{\mathbf{n}}^{X Y}\left(\mathbf{s}_{\max }\right)\right\}}\right) \frac{\mathbf{S}_{\max }}{\mathbf{2} \pi}(3)$

where $\mathbf{s}_{\max }$ means the time scale (or period) of the maximum cross wavelet power spectrum band. And the values range of atan 2 is $[-\pi, \pi]$. Although the phase difference has been defined when the cross-wavelet analysis method was developed, there are few studies on its application and to the best of the authors' knowledge, there was no previous research used this technique to analyze the relationships among $P, E T$, and TWSA in Amazon.

We performed wavelet analyses for $E T, P$, and TWSAand their coherences for four spatial resolutions: (1) averaged across the Amazon basin, (2) for 33 watersheds within the Amazon basin, (3) for individual $1 \mathrm{~km}$ scale grid cells, and (4) averaged for three zones in the Amazon basin. The underlying resolutions of $P, E T$ , and TWSA are 0.25-degree, $1 \mathrm{~km}$, and 1-degree respectively as described in Section 2.1, but $P$ and TWSA were interpolated to the same $1 \mathrm{~km}$ resolution as $E T$ to calculate the $1 \mathrm{~km}$ scale phases. Comparisons among these spatial averaging units allow us to analyze the behavior of the coherences at different spatial scales. Hereafter, we define the phases between $E T$ and $P$ at the different spatial scales as $\phi_{E T-P}^{\text {Amazon }}, \phi_{E T-P}^{\text {subbas }}, \phi_{E T-P}^{1 k m}$, and $\phi_{E T-P}^{\text {Zone }}$, and the phases between $E T$ and $T W S A$ as $\phi_{E T-T W S A}^{\text {Amazon }}, \phi_{E T-T W S A}^{\text {subbas }}, \phi_{E T-T W S A}^{1 k m}$, and $\phi_{E T-T W S A}^{\text {Zone }}$, for the whole Amazon basin, sub-basins, the individual grid cells, and three zones, respectively. A positive $\phi_{E T-P}^{\text {Amazon }}$ would mean that ETsignal leads that of $P$.

For simplicity and convenience, the time scales and wavelet power spectrum are presented using the 2-based logarithmic scale in all figures shown in the results sections below.

\subsection{Budyko framework}

The Budyko hypothesis assumes that the long-term (annual scale) partitioning of $P$ into $E T$ and runoff can be determined from available water measured as precipitation and available energy measured as potential evapotranspiration $\left(E_{P}\right)$. Based on the Budyko hypothesis, the ratio between actual evapotranspiration $\left(E_{A}\right)$ and $P$ is related to the aridity index (the ratio between $E_{P}$ and $P, \frac{E_{P}}{P}$ ), or the climate dryness index (Budyko, 1974):

$\frac{\mathbf{E}_{\mathbf{A}}}{\mathbf{P}}=\left\{\frac{\mathbf{E}_{\mathbf{P}}}{\mathbf{P}} \tanh \left(\frac{\mathbf{E}_{\mathbf{P}}}{\mathbf{P}}\right)\left[1-\cosh \left(\frac{\mathbf{P}}{\mathbf{E}_{\mathbf{P}}}\right)+\sinh \left(\frac{\mathbf{P}}{\mathbf{E}_{\mathbf{P}}}\right)\right]\right\}^{0.5}$

\section{Results and Discussion}

\subsection{Wavelet coherence and phase for Amazon-scale averaged variables}

The wavelet power spectra of spatially averaged $P, E T$, and TWSA data over the whole Amazon basin reveal, for each data set, a band of maximum power across all years with approximately a 12-month period (Figure 1a, b, and c). For ET the $95 \%$ confidence contour band ends around 2010, as there is a substantial change in the ETcycle after 2010. The pattern of a discontinuous maximum power spectrum band for ET can 
be explained by the drought event in 2010 and its monthly time series with more frequent fluctuations after 2010 than before (Figure 3b). Meanwhile, the global wavelet power spectra identify the main fluctuations of the time series (Figure 1d, e, and f) and show the 12-month peak for all three datasets and a notable, as well as a smaller, $2-4$ years peak, and some monthly-scale variations in the ET power spectrum (Figure 1e). From these analyses it is apparent that the three hydrological fluxes have significant annual cycles. Additionally, the magnitude of $E T$ global power spectra is much less than those of $P$ and TWSA ( $~ 100$ to $\sim 200$ comparing to the order of $10^{4}$ and $10^{5}$ for $P$ and TWSA respectively, Figure 1d, e, and f), indicating the periodic intensity of $E T$ is weakened due to its complicated physical and physiological processes of the plants. The non-significant multi-year $(2-4$ years) variation of ET possibly relates to long-term climatic drivers (e.g., El Nino with $\sim 3-\sim 7$ years periodicity) and its significant intra-annual ( $\sim 3$ months) variability corresponds to the succession of dry and wet seasons, suggesting that multi-climatic drivers and hydrologic responses affect $E T$ in both short-term and long-term timescales, rather than precipitation fluctuations alone.

Larger coherence indicates stronger linear correlation between two time series at the given time scale. Patches of high coherence around 1-year and multi-year periodicities between ET and $P$ and betweenET and TWSA are evident (Figure 2). It can be indicated that $E T$ has a resonant periodicity with both $P$ and TWSA at the annual scale. However, the covariation weakens substantially there since the annual cycle in $E T$ has been interrupted after 2010 (Figure 1b). Between $\sim 2006$ and $\sim 2012$, the high coherence at a $2-4$ years period (Figure 2) corresponds to the $2-4$ years fluctuation in the $E T$ wavelet spectrum (Figure $1 \mathrm{~b}$ and e). The larger correlation betweenET and TWSA than that between ET and Pindicates the drought events in 2005 and 2010 may have enhanced the effect of TWSA on ET . The cross-wavelet power spectrum between ET and $P$ also shows relatively high values at 2-4 months centered on the dry seasons of most years (Figure 2a). However, this pattern does not occur for coherence between $E T$ and $T W S A$, indicating that the impact of $P$ on $E T$ is direct (with co-variant at shorter time periods), while the impact of TWSA on ET at a shorter time scale is intervened by many factors during the deep water extraction from the aquifer by the plants' root.

For the Amazon basin, $\phi_{E T-P}^{\text {Amazon }}$ ranges from $<1$ to $\sim 4$ months, and $\phi_{E T-T W S A}^{\text {Amazon }}$ ranges from $\sim 3$ to $\sim 7$ months during 2002 to 2013 (Figure 3a), meaning that the impact of $P$ on ET is stronger than that of TWSAon $E T$ on an Amazon-wide. $\phi_{E T-P}^{\text {Amazon }}$ also reflects how responsive $E T$ is to $P$. For an area that is strongly water limited, rainfall would quickly become $E T$, and we expect to see a small lag between $E T$ and $P$ , i.e., a $\phi_{E T-P}^{\text {Amazon }}$ of around 0 . In a real-world, water-limited forest, we must also consider the time it takes for the forest to respond to increasing water supply by growing leaves and roots, which enhances its ability to transpire. Hence, we can expect a small negative $\phi_{E T-P}^{\mathrm{Amazon}}$ due to the period required for growth and the period with cloud-cover. A positive $\phi_{E T-P}^{\text {Amazon }}$, on the other hand, is quite intriguing and could possibly suggest the cloud-suppressed forest has adapted to and anticipated the coming dry season and increases leaf allocation toward the end of the rainy season, as suggested by $\mathrm{Fu}$ and $\mathrm{Li}$ (2004). A large absolute value of $\phi_{E T-P}^{\mathrm{Amazon}}$ would mean that the system is not water limited, and $E T$ may be suppressed due to too much rainfall and too little radiation relative to its canopy density. The two phases are qualitatively correlated in time, except, for example in 2010, when a severe drought occurred (Figure 3a and c). Both $\phi_{E T-T W S A}^{\text {Amazon }}$ and $\phi_{E T-P}^{\text {Amazon }}$ decreased comparing to those in 2009, but after 2010, $\phi_{E T-T W S A}^{\text {Amazon }}$ increased from $\sim 5$ month to more than 7 month while $\phi_{E T-P}^{\mathrm{Amazon}}$ remained relatively constant at $\sim 4$ month (Figure $3 \mathrm{a}$ ). In contrast, $\phi_{P-T W S A}^{\mathrm{Amazon}}$ and $\phi_{(P-E T)-T W S A}^{\text {Amazon }}$ have no correlation with $\phi_{E T-P}^{\text {Amazon }}$, but both of them decreased during the drought period and started to recover after late 2013 (Figure S1). However, the annual flux of ET has remained stable from 2002 to 2013 (Figure 3c). It could also suggest a system that ET will increase even when there is insufficient rainfall. The soil water / groundwater reserves are still maintained at a high level to provide sufficient water for ET during the meteorological dry season.

The basin spatial mean time series may mask important relationships at higher spatial resolutions. Thus, we next explore the behavior of these interactions at 33 sub-basins, $1 \mathrm{~km}$ pixel, and three zones based on $1 \mathrm{~km}$ pixel spatial scales.

\subsection{Phase lag for sub-basins of the Amazon}


To further analyze the relationship between phase lags and other climatic indicators, sub-basins within the Amazon basin are examined (Figure 4). Sub-basin \#1 is narrow, crosses almost the entire Amazon basin horizontally, and closely conforms to the Amazon River (cross hatched in Figure 4). The sub-basin delineation from Mayorga et al. (2005) is not accurate for sub-basin \#1 since it only approximates the floodplain of the main stem of Amazon River and includes minor catchments bordering the floodplain. Thus, the results for this sub-basin will not be discussed.

Inter-annual variability in $\phi_{E T-P}^{\text {subbas }}$ (blue lines) and $\phi_{E T-T W S A}^{\text {subbas }}$ (red lines) differs among the sub-basins, although coherent patterns are evident (Figure 4). $\phi_{E T-P}^{\text {subbas }}$ ranges from 5 to 8 months, generally. However, some sub-basins have either larger (10 - 12 months) (\#5, \#9, \#16, \#20, and \#25) or much smaller (\#32 and \#33) values of phase lag. Since the periodicity for all data sets is 12 months, a phase lag close to 12 months is equivalent to a small lag. Thus, $\phi_{E T-P}^{\text {subbas }}$ for those sub-basins with larger values $(10-12$ months $)$ are equivalent to $-2-0$ months, about the same as those sub-basins with smaller lags, and they are all smaller than those of other sub-basins with normal 5-8 months lag. Only the sub-basins mentioned above with smaller $\phi_{E T-P}^{\text {subbas }}$ (or $10-12$ months ones) have positive $\phi_{E T-T W S A}^{\text {subbas }}$. All these sub-basins are located in the south of the Amazon basin, which are generally water limited comparing to other sub-basins (Figure 5). The remaining sub-basins, with $5 \sim 8$ months $\phi_{E T-P}^{\text {subbas }}$, all have negative $\phi_{E T-T W S A}^{\text {subbas }}$, ranging from approximate -5 to -3 months. These sub-basins are located in the north of the Amazon basin, which are energy limited (Figure 5). For these sub-basins ET may be suppressed by excessive rainfall and low radiation. In the southern basins, the linear correlations between $\phi_{E T-P}^{\text {subbas }}$ and $\phi_{E T-T W S A}^{\text {subbas }}$ are higher (Figure 4) than those of the northern basins (red is more obvious for southern basins, meaning the correlation coefficients are larger in those basins), and the correlation is also more significant ( $p$ is significantly less than 0.05 ). It indicates that rainfall and water storage have mutual constraints in affecting ET . ET decreases as rainfall decreases. Nonetheless, the trend of $E T$ has resumed before the peak of the dry season and increased with the increase of solar radiation, showing that trees can obtain soil water / groundwater even during the peak of the dry season.

Qualitatively, north-to-south patterns of phase lag are obvious due to these sub-basins vary considerably in topography and rainfall patterns. For example, the elevation and the surface slope of the Andes mountain area and southern basins are obviously higher than those of the Amazon River basin. $P$ (Figure S2) and ET (Figure S3) present different seasonality in each subbasin. And the intensity of rainfall in each subbasin also varies (Figure S4), which also present north-south pattern. We explore the light and water limitations in the sub-basins by using Budyko analysis in the following Section.

\subsection{Budyko analysis for sub-basins}

To analyze the phase lag patterns across the sub-basins, we applied the Budyko framework (Figure 5). Since Budyko analysis is only applicable over annual or longer time frames and for large-scale watersheds, we analyzed the annual averaged data for each sub-basin. Almost all the sub-basins are energy limited, but some sub-basins $(\# 5, \# 9, \# 16$, and \#33) in some years are water limited, which are located in the south of Amazon (subplots on the bottom row of Figure 5). Plotting $\phi_{E T-P}^{\text {subbas }}$ and $\phi_{E T-T W S A}^{\text {subbas }}$ against $P E T / P$ shows that the northern and southern basins are clearly separated (Figures S5 and S6). Except for sub-basins \#2, \#4, \#6, and \#13, where PET/P is greater than $\sim 0.65$, the correlations between $\phi_{E T-P}^{\text {subbas }}$ and $\phi_{E T-T W S A}^{\text {subbas }}$ are statistically significant (Figure S7). When the linear correlation coefficients are greater than $\sim 0.6$, the correlations are significant $(p<0.05)$ (Figure S8).

Water-limited sub-basins tend to have smaller $\phi_{E T-P}^{\text {subbas }}$ (southern basins, Figures 4 and 5), which implies a less delayed $E T$ after $P$. For these southern basins, the linear correlations between $\phi_{E T-P}^{\text {subbas }}$ and $\phi_{E T-T W S A}^{\text {subbas }}$ are more statistically significant, indicating that if the immediate supply from $P$ is insufficient to maintain $E T$, groundwater plays an important role. However, if the sub-basin is not water limited, the correlation between the phase lags is not statistically significant, thus groundwater is less effectively affecting $E T$ than in those water limited sub-basins.

\subsection{Phase for kilometer scale variables}


By downscaling $P$ and TWSA to the same resolution as $E T$, we calculated $1 \mathrm{~km}$ spatial scale phase relationships between $E T$ and $P\left(\phi_{E T-P}^{1 k m} ;\right.$ Figure 6$)$ and ETand TWSA $\left(\phi_{E T-T W S A}^{1 k m}\right.$; Figure 7$)$. Large south-to-north and small east-to-west gradients occur for both phase lags across all years analyzed $(2002-2013)$. There is a band of the positive $\phi_{E T-P}^{1 k m}\left(\sim 6\right.$ month) in the middle latitudes of the Amazon basin $\left(-5^{\circ} \sim-10^{\circ}\right)$ that varies to the negative $\phi_{E T-P}^{1 k m}\left({ }^{\sim}-6\right.$ month) in north-south extent across years (Figure 6$)$, indicating that the leaf area in this area is reduced due to deforestation activities and that cloudy conditions limit the available energy driving ET(Zhang et al., 2001; Spracklen et al., 2012). Meanwhile, the location of this band of positive $\phi_{E T-P}^{1 \mathrm{~km}}$ generally corresponds to negative $\phi_{E T-T W S A}^{1 k m}$ values $\left({ }^{\sim}-6\right.$ month). The importance of plant controlling should be considered in the water balance accounting of forests in the Amazon basin, as these evergreen trees have deep root systems and can extract water from the aquifer to meet the atmospheric water demand (Maeda et al., 2017). However, deforestation interrupts the water absorption path of roots from groundwater (Zemp et al., 2017). $\phi_{E T-P}^{1 k m}$ and $\phi_{E T-T W S A}^{1 k m}$ have zero-to-positive and zero-to-negative variation patterns from 2002 to 2013, which indicate that the correlation between $E T$ and $P$ (TWSA ) has decreased in the central of Amazon region due to deforestation during the observation period (Figure 7). The increase in deforestation has weakened the carbon sink of terrestrial ecosystems. Meanwhile, Humphrey et al. (2018) proved that the inter-annual variability of the $\mathrm{CO}_{2}$ growth rate is closely related to TWSA . Considering that plant transpiration is related to $\mathrm{CO}_{2}$ absorption through leaf stomata, the variability of $E T$ is also closely associated with TWSA. A consistently positive $\phi_{E T-P}^{1 k m}$ and $\phi_{E T-T W S A}^{1 k m}$ occur in the southwest Amazon basin with high elevation. Here, in the Andes with low vegetation cover, the only source for $E T$ is snow and ice cover, and $E T$ should mostly be driven by solar radiation. Thus, in these areas $E T$ is unaffected by groundwater depth and the timing for $E T$ and groundwater variation may remain relatively constant inter-annually. The drastic transition could be artificial and regarded as the unchanged absolute value of the phase since the periodicity for all data sets is 12 months. For example, a negative 6-month phase lag is the same as a positive 6-month lag. Overall, the water-limiting areas (green) of the Amazon basin continue to shift to energy-limiting areas (blue). It could also suggest a system that switches between water and energy limitation with a growth cycle that coincidentally appears to lead rainfall, among other possibilities.

Across all $1 \mathrm{~km}$ grid cells, $\phi_{E T-P}^{1 k m}$ and $\phi_{E T-T W S A}^{1 k m}$ are not well correlated to the values of $E T, P$, or TWSA alone. Across the basin, the spatial standard deviation of annual ET is negatively correlated to that of $\phi_{E T-P}^{1 k m}$ (Figure 8; $r=-0.92$ and $R^{2}=0.85$ ). Since the inter-annual variation of $E T$ is small (Figure 3c), in some areas $E T$ and the aridity index may remain about the same regardless of annual precipitation. When the areas with low ET in dry years have recovered from water limitation, indicating ET possibly increased in these areas and the values become close to those in the unaffected areas, the overall spatial standard deviation of $E T$ decreases, but the spatial variation of $\phi_{E T-P}^{1 k m}$ becomes larger due to the generally small variation in $E T$ (Figure 8). This relationship implies that the spatial variation of $E T$ is the primary cause for the changing spatial pattern of $\phi_{E T-P}^{1 \mathrm{~km}}$ inter-annually, but this relationship does not hold for $\phi_{E T-T W S A}^{1 \mathrm{~km}}$ (data not shown). Thus, the variation of the spatial standard deviation of $E T$ means the change of $E T$ spatial heterogeneity.

\subsection{Phase lag for three zones' averaged variables}

As can be noted from the spatial variations of phases, $\phi_{E T-P}^{1 k m}$ and $\phi_{E T-T W S A}^{1 k m}$, there are north-south and east-west patterns. These patterns could indicate that there are spatially varied differences in the interaction mechanism of $E T, P$, and TWSA . To further analyze the differences, we calculated the phases for zone-averaged variables based on kilometer scale phases (Figures 6 and 7 ). The detailed method for zone partitioning is described in the supporting information (SI). Zone 1 and Zone 2 are marked by the negative phase (blue) and positive phase (yellow), respectively, while Zone 3 is for the phase approaching zero (green) (Figure S9). Zone 1 covers the north half of the Amazon basin with some scattered regions in the mid-south area. The south half part (except the scattered area of Zone 1) and some northern-most regions constitute Zone 3 except for the southwest Andes mountain and the areas with low vegetation cover, which are marked by Zone 2. The results of the phase lag for the three zones' averaged variables are shown in Figures 9, 10, and 11 , respectively. 
For Zone 1, the trends of $\phi_{E T-P}^{Z \text { one } 1}$ and $\phi_{E T-T W S A}^{Z \text { one } 1}$ are both relatively stable during 2002 to 2013 (Figure 9a). The monthly peak and trough of $P$ and $E T$ are out of phase (Figure $9 \mathrm{~b}$ ). The annual $P$ in this zone is larger than those in other zones (Figures 9c, 10c, and 11c), which implies that larger $P$ (and less radiation) suppresses $E T$. In addition, the phases slight increase in drought years, suggesting the suppression of $P$ on $E T$ decreases along with the reduction of $P$ and cloud-cover. The small variations of two phases relate to sufficient $P$, indicating the drought events may have weak impact on the $E T$ in Zone 1 . The suppression of $E T$ in Zone 1 is most likely that the cloudy conditions limit the energy available to driveET . Thus, this area is considered to be light limited.

As Zone 2 has mountain areas that are covered by low vegetation, snow and ice, and therefore $E T$ is mainly driven by solar radiation. The drought event in 2005 promotes the impact of rainfall on ET(Figure 10a), indicating that Zone 2 was also water limited, which corresponds to the Budyko analysis. The time series of $P$ and $E T$ are resonant before 2005. However, the monthly peak and trough of $P$ and $E T$ time series are offset and the amplitude of TWSA variation slightly increases after 2005 (Figure 10b). These patterns could indicate that $P$ has a positive effect on ETbefore 2005, and suppresses ET after 2005.

The variations of phases for Zone 3 averaged variables correspond well to the drought events (Figure 11). This is the regime with higher aridity index (the lowest annual averaged $P$ among three zones), where $P$ is not large enough to suppress ET and is therefore water limited, and this is corroborated in the Section 3.3. The variations of phases for Zone 3 are also relatively similar to those at the whole Amazon scale (Figure 3). The close response of $\phi_{E T-P}^{Z \text { one }} 3$ to the variation of the annual $P$ supports the hypothesis that when $P$ is small, $E T$ relies on rapid evaporation of rainfall. The large variation and the similar response of $\phi_{E T-T W S A}^{Z \text { one }}{ }^{3}$ to the annual $P$ indicate that groundwater supports $E T$ during the dry periods (Figure 11a) via water supply mechanism (rooting depth and groundwater) and vegetation water requirement (Christoffersen et al., 2014).

ET presents different seasonality in different zones (Figure S9). In August and September, it peaks in Zone 1 while is lowest in Zone 2 with the largest variation. In Zone 3, the lowest ET occurs in June (Figure S10). The seasonality of precipitation in Zone 2 and 3 are similar, but it is slightly different in Zone 1 (Figure S11). The precipitation in Zone 3 is much more intense as there are many more days with daily rainfall larger than $20 \mathrm{~mm}$, which is not the case for Zones 1 and 2. Therefore, controls of ET across the different area of the Amazon basin vary. Evaporation demand (especially net radiation) plays a more important role in wetter forests, and soil moisture (or $P$ ) has larger affects in the relative drier area (Rocha et al., 2009). The soil water storage still remains relatively large after the start of the dry season (i.e. when rainfall is small). When the soils reach their lower water storage capacity, 3 months after the peak of the dry season, the rainy season has already started to provide enough water supply for plants. Therefore, the annual flux of ET remains relatively stable in dry years.

\section{Conclusions}

Using wavelet coherence analysis, we found that Amazon-scale averaged evapotranspiration ( $E T$ ) has strong correlations with precipitation $(P)$ and the total water storage anomaly (TWSA) at the annual and multiyear $(\sim 2$ to $\sim 4$ year) periodicities. But the strong annual periodicity was no longer significant due to irregular short-term pattern of ET after 2010 (drought event). Moreover, at multi-year scale the correlation from 2006 to 2012, possibly indicating that external climate drivers (drought and El Nino events) have enhanced the impact of groundwater on ET . The spatial distributions of $\phi_{E T-P}^{1 k m}$ and $\phi_{E T-T W S A}^{1 k m}$ across the Amazon basin have clear large south-north and small east-to-west patterns, and our Budyko framework analysis demonstrates that the water and energy limitation conditions vary significantly between the northern and southern sub-basins of the Amazon. Although the Amazon basin is generally energy limited, some southern sub-basins are water limited in some years. $\phi_{E T-P}^{\text {subbas }}$ and $\phi_{E T-T W S A}^{\text {subbas }}$ are also well correlated in the southern Amazon. The strength and significance of their correlations are affected by the aridity index $(P E T / P)$ of each sub-basin. The spatial heterogeneity of $\phi_{E T-P}^{1 \mathrm{~km}}$ is negatively correlated with the spatial variation of annual $E T$, which implies that the spatial variation of $E T$ is the primary cause for the changing pattern of $\phi_{E T-P}^{1 k m}$ inter-annually. $\phi_{E T-P}^{1 k m}$ and $\phi_{E T-T W S A}^{1 k m}$ show the dynamic changes of the spatiotemporal correlation among $E T, P$, and TWSA. The water limited area gradually decreases due to the frequent deforestation 
in the southern Amazon basin.

The results of the three zones analysis also confirm that the effect of drought on ET has the south-north patterns. The drought events have weak impact on $E T$ with sufficient annual $P$ in the northern Amazon basin, and in the southwest Amazon basin as well, where the main source of ET in the mountain areas is snow and ice cover. But the variation of phase in the southeast Amazon basin is closely related to the drought events. During the drought year (2010), the decreased phases ( $\phi_{E T-P}^{\text {Amazon }}$ and $\left.\phi_{E T-T W S A}^{\text {Amazon }}\right)$ likely indicate that $E T$ was supported by both rainfall and groundwater to maintain the same yield compared to the years with sufficient $P$. After the drought year, when the watershed was no longer water limited, $\phi_{E T-T W S A}^{\text {Amazon }}$ increased rapidly, possibly implying the groundwater system had recovered and ET was not immediately supported by groundwater but by $P$, since $\phi_{E T-P}^{\text {Amazon }}$ is much smaller than $\phi_{E T-T W S A}^{\text {Amazon }}$ during this recovery period. Thus, Amazon-wide annual $E T$ is possibly not limited by rainfall availability since groundwater plays an important role during dry years.

The energy and water limitations are switched in some regions over time. Whether ET is driven by lightlimited or water-limited needs to be studied separately in specific areas. This work expounds a deeper understanding of the control of ET in different regions in the Amazon basin by studying the phase lag between two variables at different scales. However, in most cases, the seasonality of ETis driven by the balance between radiation, rainfall, and vegetation regulations, rather than being completely limited by any one of these factors. Vegetation phenology further increases the complexity of studying the relative importance of controlling ET factors in the Amazon basin. Future, we expect to add datasets about radiation and vegetation to further analyze the factors of controlling ET in the Amazon basin.

\section{Acknowledgements}

This research was partially supported by NSF project of Guangdong, China under Contract 2018A030313165, and by the Director, Office Science, Office of Biological and Environmental Research of the U.S. Department of Energy under Contract DE-0010620 as part of their Earth System Modeling and NGEE-Tropics Program.

\section{Data Availability Statement}

All data used in this study are publicly available online and can be accessed through the links provided in the manuscript. All models or code generated or used during the study are available from the corresponding author by request.

\section{References:}

Andreo, B., Jimenez, P., Duran, J. J., Carrasco, F., Vadillo, I., \& Mangin, A. (2006). Climatic and hydrological variations during the last 117 - 166 years in the south of the Iberian Peninsula, from spectral and correlation analyses and continuous wavelet analyses. Journal of Hydrology, 324 , 24-39. https://doi.org/10.1016/j. jhydrol.2005.09.010

Bonan, G. B., Levis, S., Kergoat, L., \& Oleson, K. W. (2002). Landscapes as patches of plant functional types: An integrating concept for climate and ecosystem models. Global Biogeocheical Cycles , 16, 5-1-5-23. https://doi.org/10.1029/2000GB001360

Brando, P. M., Goetz, S. J., Baccini, A., Nepstad, D. C., Beck, P. S. A., \& Christman, M. C. (2010). Seasonal and interannual variability of climate and vegetation indices across the Amazon. Proceedings of the National Academy of sciences of the United States of America ,107 , 14685-14690. https://doi.org/ 10.1073/pnas.0908741107

Briggs, J. M., \& Knapp, A. K. (1995). Interannual Variability in Primary Production in Tallgrass Prairie: Climate, Soil Moisture, Topographic Position, and Fire as Determinants of Aboveground Biomass.American Journal of Botany , 82 , 1024-1030. https://doi.org/10.2307/2446232

Budyko, M. I. (1974). Climate and Life. Academic Press, New York. 
Carabajal, C. C., \& Harding, D. J. (2006). SRTM C-Band and ICEsat Laser Altimetry Elevation Comparisons as a Function of Tree Cover and Relief.Photogrammetric Engineering 8 Remote Sensing , 72 , 287-298. https://doi.org/10.14358/PERS.72.3.287

Christoffersen, B. O., Restrepo-Coupe, N., Arain, M. A., Baker, I. T., Cestaro, B. P., Ciais, P., Fisher, J. B., Galbraith, D., Guan, X. D., Gulden, L., Hurk, B. V. D., Ichii, K., Imbuzeiro, H., Jain, A., Levine, N., Miguez-Macho, G., Poulter, B., Roberti, D. R., Sakaguchi, K., Sahoo, A., Schaefer, K., Shi, M., Verbeeck, H., \& Yang, Z. L. (2014). Mechanisms of water supply and vegetation demand govern the seasonality and magnitude of evapotranspiration in Amazonia and Cerrado.Agricultural and Forest Meteorology, 191 , 33-50. https://doi.org/ 10.1016/j.agrformet.2014.02.008

Costa, M. H., Biajoli, M. C., Sanches, L., Malhado, A., Hutyra, L. R., \& Da Rocha, H. R. (2010). Atmospheric. versus vegetation controls of Amazonian tropicalrain forest evapotranspiration: are the wet and seasonally dry rain forests any different? Journal of Geophysical Research: Biogeosciences , 115 , 1-9. https://doi.org/ 10.1029/2009JG001179

Culf, A. D., Foken, T., \& Gash, J. H. C. (2008). The energy balance closure problem: an overview. Ecological Applications , 18 , 1351-1367. https://doi.org/10.1890/06-0922.1

Danko, D. M. (1992). The digital chart of the world.Photogrammetric Engineering and Remote Sensing , 58 . https://doi.org/10.1016/0924-2716(92)90041-7

Daubechies, I. (1990). The wavelet transform, time-frequency localization and signal analysis. Information Theory, IEEE Transactions on 36 , 961-1005. https://doi.org/10.1063/1.4928520

Doughty, C. E., \& Goulden, M. L. (2008). Seasonal patterns of tropical forest leaf area index and $\mathrm{CO}_{2}$ exchange. Journal of Geophysical Research-Biogeoscience 113 , n/a-n/a. https://doi/org/10.1029/2007JG000590

Doughty, C. E., Metcalfe, D. B., Girardin, C. A. J., Amézquita, F. F., Cabrera, D. G., Huasco, W. H., Silva-Espejo, J. E., Araujo-Murakami, A., da Costa, M. C., Rocha, W., Feldpausch, T. R., Mendoza, A. L. M., da Costa, A. C. L., Meir, P., Phillips, O. L., \& Malhi, Y. (2015). Drought impact on forest carbon dynamics and fluxes in Amazonia. Nature ,519, 78-82. https://doi.org/10.1038/nature14213

Fan, Y., Li, H., \& Miguez-Macho, G. (2013). Global Patterns of Groundwater Table Depth. Science , 339 , 940-943. https://doi.org/10.1126/science.1229881

Feng, X., Porporato, A., \& Rodriguez-Iturbe, I. (2013). Changes in rainfall seasonality in the tropics. National Climate Change ,3 , 811-815. https://doi.org/10.1038/nclimate1907

Franken, W., \& Leopoldo, P. R. (1984). The Amazon-Limnology and landscape ecology of a mighty tropical river and its basin. Dr W. Junk Publishers. https://doi.org/10.1007/978-94-009-6542-3_27

Fu, R., \& Li, W. (2004). The influence of the land surface on the transition from dry to wet season in Amazonia. Theoretical and Applied Climatology , 78 , 97-110. https://doi.org/10.1007/s00704-004-0046-7

Guber, A. K., Pachepsky, Y. A., van Genuchten, M. T., Rawls, W. J., Simunek, J., Jacques, D., Nicholson, T. J., \& Cady, R. E. (2006). Field-Scale Water Flow Simulations Using Ensembles of Pedotransfer Functions for Soil Water Retention. Vadose Zone Journal ,5 , 234-247. https://doi.org/10.2136/vzj2005.0111

Hasler, N., \& Avissar, R. (2006). What controls evapotranspiration in the amazon basin? Journal of Hydrometeorology , 8 , 380-395. https://doi.org/10.1175/JHM587.1

Hilker, T., Lyapustin, A. I., Tucker, C. J., Hall, F. G., Myneni, R. B., Wang, Y., Bi, J., Mendes de Moura, Y., \& Sellers, P. J. (2014). Vegetation dynamics and rainfall sensitivity of the Amazon.Proceedings of the National Academy of sciences of the United States of America , 111 , 16041-16046. https://doi.org/10.1073/ pnas. 1404870111 
Hodnett, M. G., Vendrame, I., Filho, A. D. O. M., Oyama, M. D., \& Tomasella, J. (1997). Soil water storage and groundwater behaviour in a catenary sequence beneath forest in central Amazonia: i. comparisons between plateau, slope and valley floor. Hydrology and Earth System Sciences , 1 , 279-290. https://doi.org/ 10.5194/hess-1-265-1997

Huete, A. R., Didan, K., Shimabukuro, Y. E., Ratana, P., Saleska, S. R., Hutyra, L. R., Yang, W., Nemani, R. R., \& Myneni, R. (2006). Amazon rainforests green-up with sunlight in dry season. Geophysical Research Letters , 33 , 272-288. https://doi.org/10.1029/2005GL025583

Humphrey, V., Zscheischler, J., Ciais, P., Cudmundsson, L., Sitch, S., \& Seneviratne, S. I. (2018). Sensitivity of atmospheric $\mathrm{CO}_{2}$ growth rate to observed changes in terrestrial water storage. Nature , 560 , 628-631. https:// doi.org/10.1038/s41586-018-0424-4

Huxman, T. E., Snyder, K. A., Tissue, D., Leffler, A. J., Ogle, K., Pockman, W. T, Sandquist, D. R., Potts, D. L., \& Schwinning, S. (2004). Precipitation pulses and carbon fluxes in semiarid and arid ecosystems. Oecologia , $141,254-268$. https://doi.org/10.1007/s00442-004-1682-4

Jones, M. O., Kimball, J. S., \& Nemani, R. R. (2014). Asynchronous Amazon forest canopy phenology indicates adaptation to both water and light availability. Environmental Research Letters , 9 , 124021. https://doi.org/ 10.1088/1748-9326/9/12/124021

Kleidon, A., \& Heimann, M. (2000). Assessing the role of deep rooted vegetation in the climate system with model simulations: mechanism, comparison to observations and implications for Amazonian deforestation.Climate Dynamics , 16 , 183-199. https://doi.org/10.1007/s003820050012

Labat, D. (2005). Recent advances in wavelet analyses: Part 1. A review of concepts. Journal of Hydrology , 314 , 275-288. https://doi.org/10.1016/j.jhydrol.2005.04.003

Labat, D., Ronchail, J., \& Guyot, J. L. (2005). Recent advances in wavelet analyses: Part 2-Amazon, Parana, Orinoco and Congo discharges time scale variability. Journal of Hydrology , 314 , 289-311. https://doi. org/10.1016/j.jhydrol.2005.04.004

Lai, C. T., \& Katul, G. (2000). The dynamic role of root-water uptake in coupling potential to actual transpiration. Advances in Water Resources, 23 , 427-439. https://doi.org/10.1016/S0309-1708(99)00023-8

Landerer, F. W., \& Swenson, S. C. (2012). Accuracy of scaled GRACE terrestrial water storage estimates. Water Resources Research ,48 , 4531. https://doi.org/10.1029/2011WR011453

Leopoldo, P. R., Franken, W. K., \& Villa Nova, N. A. (1995). Real evapotranspiration and transpiration through a tropical rain forest in central Amazonia as estimated by the water balance method. Forest Ecology Es Management, 73 , 185-195. https://doi.org/10.1016/0378-1127(94)03487-H

Lesack, L. F. W. (1993). Water balance and hydrologic characteristics of a rain forest catchment in the central Amazon Basin. Water Resources Research , 29 , 759-773. https://doi.org/10.1029/92WR02371

Lettau, H., Lettau, K., \& Molion, L. C. B. (1979). Amazonia's Hydrologic Cycle and the Role of Atmospheric Recycling in Assessing Deforestation Effects. Monthly Weather Review , 107 , 227. https://doi.org/10.1175/ 1520-0493(1979) $107<0227:$ AHCATR > 2.0.CO;2

Maeda, E. E., Ma, X., Wagner, F. H., Kim, H., Oki, T., Eam D., \& Huete, A. (2017). us, Evapotranspiration seasonality across the Amazon Basin.Earth System Dynamics Discussions , 8 , 439-454. https://doi.org/ 10.5194/esd-2016-75

Malhi, Y., Pegoraro, E., Nobre, A. D., Pereira, M. G. P., Grace, J., Culf, A. D., \& Clement, R. (2002). Energy and water dynamics of a central Amazonian rain forest. Journal of Geophysical Research: Atmospheres , 107 , 8061. https://doi.org/10.1029/2001JD000623

Mayorga, E., Logsdon, M. G., Ballester, M. V. R., \& Richey, J. E. (2005). Estimating cell-to-cell land surface drainage paths from digital channel networks, with an application to the Amazon basin. Journal of Hydrology 
, 315, 167-182. https://doi.org/10.1016/j.jhydrol.2005.03.023

Miguez-Macho, G., \& Fan, Y. (2012a). The role of groundwater in the Amazon water cycle: 1. Influence on seasonal streamflow, flooding and wetlands. Journal of Geophysical Research: Atmospheres ,117, 1-30. https://doi.org/10.1029/2012JD017539

Miguez-Macho, G., \& Fan, Y. (2012b). The role of groundwater in the Amazon water cycle: 2. Influence on seasonal soil moisture and evapotranspiration. Journal of Geophysical Research: Atmospheres ,117, D15114. https://doi.org/10.1029/2012JD017540

Molénat, J., Davy, P., Gascuel-Odoux, C., \& Durand, P. (1999). Study of three subsurface hydrologic systems based on spectral and cross-spectral analysis of time series. Journal of Hydrology , 222 , 152-164. https://doi.org/ 10.1016/S0022-1694(99)00107-9

Mooney, H. A., Dirzo, R., Ceballos, G., \& Young, H. S. (2011). Seasonally dry tropical forests: ecology and conservation. Seasonally Dry Tropical Forests .

Morton, D.C., Nagol, J., Carabajal, C.C., Rosette, J., Palace, M., Cook, B.D., Vermote, E.F., Harding, D.J., North, P.R.J., 2014. Amazon forests maintain consistent canopy structure and greenness during the dry season. Nature , 506 , 221-224. https://doi.org/10.1038/nature13006

Mu, Q., Heinsch, F.A., Zhao, M., Running, S.W., 2007. Development of a global evapotranspiration algorithm based on MODIS and global meteorology data. Remote Sensing of Environment , 106 , 285-304. https://doi.org/10.1016/j.rse.2006.07.007

Mu, Q., Zhao, M., Running, S.W., 2011. Improvements to a MODIS global terrestrial evapotranspiration algorithm. Remote Sensing of Environment , 115 , 1781-1800. https://doi.org/10.1016/j.rse.2011.02.019

Myneni, R. B., Yang, W., Nemani, R. R., Huete, A. R., Dickinson, R. E., Knyazikhin, Y., Didan, K., Fu, R., Negron Juarez, R. I., Saatchi. S. S., Hashimoto, H., Ichii, K., Shabanov, N. V., Tan, B., Ratana, P., Privette, J. L., Morisette, J. T., Vermote, E. F., Roy, D. P., Wolfe, R. E., Friedl, M. A., Running, S. W., Votava, P., El-Saleous, N., Devadiga, S., Su, Y., \& Salomonson, V. V. (2007). Large seasonal swings in leaf area of Amazon rainforests. Proceedings of the National Academy of sciences of the United States of America, 104 , 4820-4823. https://doi.org/10.1073/pnas.0611338104

Nemani, R.R., 2003. Climate-Driven Increases in Global Terrestrial Net Primary Production from 1982 to 1999. Science , 300 , 1560-1563. https://doi.org/10.1126/science.1082750

Nepstad, D. C., de Carvalho, C. R., Davidson, E. A., Jipp, P. H., Lefebvre, P. A., Negreiros, G. H., da Silva, E. D., Stone, T. A., Trumbore, S. E., \& Vieira, S. (1994). The role of deep roots in the hydrological and carbon cycles of Amazonian forests and pastures, Nature , 372 , 666-669. https://doi.org/10.1038/372666a0

Niu, J., Shen, C., Chambers, J. Q., Melack, J. M., \& Riley, W. J. (2017). Interannual Variation in Hydrologic Budgets in an Amazonian Watershed with a Coupled Subsurface - Land Surface Process Model.Journal of Hydrometeorology , 18 , 2597-2617. https://doi.org/10.1175/JHM-D-17-0108.1

Nobre, A. D., Cuartas, L. A., Hodnett, M., Rennó, C. D., Rodrigues, G., Silveira, A., Waterloo, M., \& Saleska, S. (2011). Height Above the Nearest Drainage - a hydrologically relevant new terrain model.Journal of Hydrology , 404 , 13-29. https://doi.org/10.1016/j.jhydrol.2011.03.051

Oleson, K. W., Lawrence, D. M., Bonan, G. B., Drewniak, B., Huang ,M., Charles, D., Levis, S., Li, F., Riley, W. J., Zachary, M., Swenson, S. C., Thornton, P. E., Bozbiyik, A., Fisher, R., Heald, C. L., Kluzek, E., Lamarque, F., Lawrence, P. J., Leung, L. R., Muszala, S., Ricciuto, D. M., \& Sacks, W. (2013). Technical description of version 4.5 of the Community Land Model (CLM). National Central Atmosphere Research Boulder, CO 420pp. https://doi.org/10.5065/D6RR1W7M

Piao, S., Ito, A., Li, S., Huang, Y., Ciais, P., Wang, X., Peng, S., Andres, R. J., Fang, J., Jeong, S., Mao, J., Mohammat, A., Muraoka, H., Nan, H., Peng, C., Peylin, P., Shi, X., Sitch, S., Tao, S., Tian, H., Xu, M., 
Yu, G., Zeng, N., \& Zhu, B. (2012). The carbon budget of terrestrial ecosystems in East Asia over the last two decades.Biogeosciences , 9 , 4025-4066. https://doi.org/10.5194/bg-9-3571-2012

Restrepo-Coupe, N., Levine, N. M., Christoffersen, B. O., Albert, L. P., Wu, J., Costa, M. H., Galbraith, D., Imbuzeiro, H., Martins, G., da Araujo, A. C., Malhi, Y. S., Zeng, X., Moorcroft, P., \& Saleska, S. R. (2016). Do dynamic global vegetation models capture the seasonality of carbon fluxes in the Amazon basin? A data-model intercomparison. Global Change Biology ,1-18. https://doi.org/10.1111/gcb.13442

Rocha, H. R. D., Manzi, A. O., Cabral, O. M., Miller, S. D., Goulden, M. L., \& Saleska, S. R. (2015). Patterns of water and heat flux across a biome gradient from tropical forest to savanna in brazil. Journal of Geophysical Research Biogeosciences , 114 , 579-581. https://doi.org/10.1029/2007JG000640

Salati, E., Dall'Olio, A., Matsui, E., \& Gat, J. R., (1979). Recycling of water in the Amazon Basin: An isotopic study. Water Resources Research , 15 , 1250. https://doi.org/10.1029/WR015i005p01250

Saleska, S. R., Miller, S. D., Matross, D. M., Goulden, M. L., Wofsy, S. C., da Rocha, H. R., de Camargo, P. B., Crill, P., Daube, B. C., de Freitas, H. C., Hutyra, L., Keller, M., Kirchhoff, V., Menton, M., Munger, J. W., Pyle, E. H., Rice, A. H., \& Silva, H. (2003). Carbon in Amazon forests: unexpected seasonal fluxes and disturbance-induced losses. Science , 302 , 1554-1557. https://doi.org/10.1126/science.1091165

Samanta, A., Knyazikhin, Y., Xu, L., Dickinson, R. E., Fu, R., Costa, M. H., Saatchi, S. S., Nemani, R. R., \& Myneni, R. B. (2012). Seasonal changes in leaf area of Amazon forests from leaf flushing and abscission. Journal of Geophysical Research Biogeosciences ,117 , 75-81. https://doi.org/10.1029/2011JG001818

Schaefli, B., Maraun, D., \& Holschneider, M. (2007). What drives high flow events in the Swiss Alps? Recent developments in wavelet spectral analysis and their application to hydrology. Advances in Water Resources , $30,2511-2525$. https://doi.org/10.1016/j.advwatres.2007.06.004

Shen, C., Niu, J., \& Phanikumar, M. S. (2013). Evaluating controls on coupled hydrologic and vegetation dynamics in a humid continental climate watershed using a subsurface-land surface processes model. Water Resources Research , 49 , 552-2572. https://doi.org/10.1002/wrcr.20189

Shen, C., \& Phanikumar, M.S. (2010). A process-based, distributed hydrologic model based on a large-scale method for surface-subsurface coupling. Advances in Water Resources , 33 , 1524-1541. https://doi.org/ 10.1016/j.advwatres.2010.09.002

Simard, M., Pinto, N., Fisher, J. B., \& Baccini, A. (2011). Mapping forest canopy height globally with spaceborne lidar. Journal of Geophysical Research Biogeosciences , 116 , 1-12. https://doi.org/10.1029/ 2011JG001708

Spracklen, D. V., Arnold, S. R., \& Taylor, C. M. (2012). Observations of increased tropical rainfall preceded. by air passage over forests. Nature, 489, 282-285. https://doi.org/10.1038/nature11390

Swann, A. L. S., \& Koven, C. D. (2017) A direct estimate of the seasonal cycle of evapotranspiration over the amazon. basin. Journal of Hydrometeorology . https://doi.org/10.1175/JHM-D-17-0004.1

Swenson, S. C., \& Wahr, J. (2006). Post-processing removal of correlated errors in GRACE data. Geophysical Research Letters ,33 , L08402. https://doi.org/10.1029/2005GL025285

Tang, J., Riley, W. J., \& Niu, J. (2015). Incorporating root hydraulic redistribution in CLM4.5: Effects on predicted site and global evapotranspiration, soil moisture, and water storage. Journal of Advances in Modeling Earth Systems , 7 , 1828-1848. https://doi.org/10.1002/2015MS000484

Tomasella, A. J., \& Hodnett, M. G. (1998). Estimating soil water retention characteristics from limited data in Brazilian Amazonia.Soil Science, 163 , 190-202. https://doi.org/10.1097/00010694-199803000-00003

Torrence, C., \& Compo, G. P. (1998). A Practical Guide to Wavelet Analysis. Bulletin of the American Meteorological Society ,79 , 61-78. https://doi.org/10.1175/1520-0477(1998)079<0061:APGTWA >2.0. CO;2 
van Genuchten, M. T. (1980). A Closed-form Equation for Predicting the Hydraulic Conductivity of Unsaturated Soils1. Soil Science Society of America Journal . https://doi.org/10.2136/sssaj1980.0361599500440005 $0002 \mathrm{x}$

Wagner, F. H., Hérault, B., Bonal, D., Stahl, C., Anderson, L. O., Baker, T. R., Becker, G. S., Beeckman, H., Boanerges Souza, D., Botosso, P. C., Bowman, D. M. J. S., Bräuning, A., Brede, B., Brown, F. I., Camarero, J. J., Camargo, P. B., Cardoso, F. C. G., Carvalho, F. A., Castro, W., Chagas, R. K., Chave, J., Chidumayo, E. N., Clark, D. A., Costa, F. R. C., Couralet, C., da Silva Mauricio, P. H., Dalitz, H., de Castro, V. R., de Freitas Milani, J. E., de Oliveira, E. C., de Souza Arruda, L., Devineau, J-L., Drew, D. M., Dünisch, O., Durigan, G., Elifuraha, E., Fedele, M., Ferreira Fedele, L., Figueiredo Filho, A., Finger, C. A. G., Franco, A. C., Freitas Júnior, J. L., Galvão, F., Gebrekirstos, A., Gliniars, R., Graça, P. M. L., de, A., Griffiths, A. D., Grogan, J., Guan, K., Homeier, J., Kanieski, M. R., Kho, L. K., Koenig, J., Kohler, S. V., Krepkowski, J., Lemos-Filho, J. P., Lieberman, D., Lieberman, M. E., Lisi, C. S., Longhi Santos T, López Ayala, J. L., Maeda, E. E., Malhi, Y., Maria, V. R. B., Marques, M. C. M., Marques, R., Maza, C. H., Mbwambo, L., Melgaço, K. L. L., Mendivelso, H. A., Murphy, B. P., O'Brien, J. J., Oberbauer, S. F., Okada, N., Pélissier, R., Prior, L. D., Roig, F. A., Ross, M., Rossatto, D. R., Rossi, V., Rowland, L., Rutishauser, E., Santana, H., Schulze, M., Selhorst, D., Silva, W. R., Silveira, M., Spannl, S., Swaine, M. D., Toledo, J. J., Toledo, M. M., Toledo, M., Toma, T., Tomazello, F. M., Valdez Hernández, J. I., Verbesselt, J., Vieira, S. A., Vincent, G., Volkmer de Castilho, C., Volland, F., Worbes, M., Zanon, M. L. B., \& Aragão, L. E. O. C. (2016). Climate seasonality limits leaf carbon assimilation and wood productivity in tropical forests.Biogeoscience, 13 , 2537-2562. https://doi.org/10.5194/bg-13-2537-2016

Wang, D. (2012). Evaluating interannual water storage changes at watersheds in Illinois based on long-term soil moisture and groundwater level data. Water Resources Research , 48 , n/a-n/a. https://doi.org/10.1029/ 2011 wr010759

Weltzin, J. F., Loik, M. E., Schwinning, S., Williams, D. G., Fay, P. A., Haddad, B. M., Harte, J., Huxman, T. E., Knapp, A. K., Lin, G., Pockman, W. T., Shaw, M. R., Small, E. E., Smith, M. D., Smith, S. D., Tissue, D. T., \& Zak, J. C. (2003). Assessing the Response of Terrestrial Ecosystems to Potential Changes in Precipitation.Bioscience. 53 , 941-952. https://doi.org/10.1641/0006-3568(2003)053[0941:ATROTE]2.0. $\mathrm{CO} ; 2$

Werth, D., \& Avissar, R. (2004). The regional evapotranspiration of the Amazon. Journal of Hydrometeorology , 5,100-109. https://doi.org/10.1175/1525-7541(2004)005<0100:TREOTA > 2.0.CO;2

Wilson, K., Glodstein, A., Falge, E., Aubinet, M., Baldocchi, D., Berbigier, P., Bernhofer, C., Ceulemans, R., Dolman, H., Field, C., Grelle, Grelle, A., Ibrom, A., Law, B. E., Kowalski, A., Meyers, T., Moncrieff, J., Monson, R., Oechel, W., Tenhunen, J., Valentini, R., \& Verma, S. (2002). Energy balance closure at fluxnet sites.Agricultural and Forest Meteorology , 113 , 223-243. https://doi.org/10.1016/S0168-1923(02)00109-0

Yang, D., Sun, F., Liu, Z., Cong, Z., Ni, G., \& Lei, Z. (2007). Analyzing spatial and temporal variability of annual water-energy balance in nonhumid regions of China using the Budyko hypothesis. Water Resources Research , 43 , 436-451. https://doi.org/10.1029/2006WR005224

Zemp, D. C., Schleussner, C. F., Barbosa, H. M. J., \& Rammig, A. (2017). Deforestation effects on Amazon. forest resilience. Geophysical Research Letters , 44 . https://doi.org/10.1002/2017GL072955

Zhang, J., Hao, Y., Hu, X., Huo, X., \& Hao, P. (2016). The effects of monsoons and climate teleconnections on the Niangziguan Karst Spring discharge in North China. Climate Dynamics , 48 , 53. https://doi.org/10.1007/ s00382-016-3062-2

Zhang, L., Dawes, W. R., \& Walker, G. R. (2001). Response of mean annual evapotranspiration to vegetation. changes at catchment scale. Water Resources Research, 37, 701-708. https://doi.org/10.1029/2000WR 900325

Figures 
Figure 1. Contour plots of wavelet power spectra of precipitation (a), ET (b), and TWSA (c), and global wavelet spectra of precipitation (d), ET (e) and TWSA (f). The x-axes of subplots (a), (b), and (c) represent the time, the y-axis represents the periodicity scale, and the color represents the magnitude of the wavelet coefficient. The contour lines enclose regions of greater than $95 \%$ confidence (Torrence \& Compo, 1998). The x-axes of subplots (d), (e), and (f) represent the power of global wavelet spectrum.

Figure 2. Cross wavelet power spectra of $E T$ and $P(\mathrm{a})$, and $E T$ and $T W S A$ (b). The contour plots represent the power of cross spectra and are shown as blank when the values are smaller than $2^{-8}$. The arrows represent the phase relationship between these time series and are only presented when the wavelet power is greater than $2^{-2}$.

Figure 3. Plots of phase lags (a) between $E T$ and $P\left(\phi_{E T-P}^{\mathrm{Amazon}}\right)$, and between $E T$ and $T W S A\left(\phi_{E T-T W S A}^{\mathrm{Amazon}}\right)$; monthly time series data (b) of $P, T W S A$, and $E T$; and annual averaged data (c) of $P, E T$, and $P$ $E T$. All time series data are spatially-averaged over the Amazon, and the phase lags are calculated based on the spatially-averaged monthly time series data.

Figure 4. Sub-basins of Amazon (center subplot) and the phase lags between $E T$ and $P\left(\phi_{E T-P}^{\text {subbas }}\right)$, and between $E T$ and $T W S A\left(\phi_{E T-T W S A}^{\text {subbas }}\right)$ (subplots $\left.1-33\right)$. The color saturation in the center sub-plot indicates the linear correlation coefficients between $\phi_{E T-P}^{\text {subbas }}$ and $\phi_{E T-T W S A}^{\text {subbas }}$. Darker means higher correlation as shown in the legend. The location of subplots $1-33$ are generally corresponding to the geographical position as shown in the center subplot. Subplots 1 - 33 also show the linear correlation coefficients and $p$-values for testing the hypothesis of no correlation against the alternative that there is a nonzero correlation. If $p$ is small (i.e., $p<0.05$ ), then the correlation is significantly different from zero. The x-axes of subplots $1-33$ are the time (year), the left y-axes of them are $\phi_{E T-P}^{\text {subbas }}$ and the right ones are $\phi_{E T-T W S A}^{\text {subbas }}$.

Figure 5. The Budyko framework applied to 33 sub-basins of Amazon. In each subplot, the x-axes are the ratio between potential evapotranspiration and precipitation $(P E T / P)$; the y-axes are the ratio between actual ET and precipitation $(E T / P)$; the solid horizontal line indicates water limitation (i.e., annual $E T$ $=$ annual $P$ ); the 1:1 line indicates energy limitation (annualET = annual $P E T$ ); the dashed vertical line indicates the boundary between these limitations; and the dots are the annual averaged data for each subbasin. The label of each subplot corresponds to the index of each sub-basin (see Figure 4) and the positions of them are generally corresponding to the geographical location of each sub-basin.

Figure 6. Map of the pixel-by-pixel phase lag between ETand $P\left(\phi_{E T-P}^{1 \mathrm{~km}}\right)$ for each year from 2002 to 2013. Different colors represent different phase lags in time (month) as shown in the legend. Missing data from either $E T$ or $P$ are shown as blank.

Figure 7. Map of the pixel-by-pixel phase lag between ETand TWSA $\left(\phi_{E T-T W S A}^{1} \mathrm{~km}\right.$ ) for each year from 2002 to 2013. Different colors represent different phase lags in time (month) as shown in the legend. Missing data from either $E T$ or TWSA are shown as blank.

Figure 8. Correlation plot of the spatial standard deviation of the pixel-by-pixel annual averaged phase lag between $E T$ and $P\left(\sigma_{E T-P}^{\text {pixel }}\right)$ and the standard deviation of annual averaged $E T(\sigma \mathrm{ET})$. The dots are the data and the solid line is the fitting curve.

Figure 9. Plots of (a) phases between $E T$ and $P\left(\phi_{E T-P}^{Z \text { one }} 1\right)$, and between $E T$ and $T W S A\left(\phi_{E T-T W S A}^{Z \text { Zone }} 1\right.$; (b) monthly time series of $P, T W S A$, and $E T$; and (c) annual averages of $P, E T$, and $P-E T$. All time series data are spatially averaged over Zone 1 , and the phases are calculated based on the spatially averaged monthly variables of Zone 1.

Figure 10. Plots of (a) phases between $E T$ and $P\left(\phi_{E T-P}^{Z O n e}{ }^{2}\right)$, and between $E T$ and $T W S A\left(\phi_{E T-T W S A}^{Z \text { one }}{ }^{2}\right.$; (b) monthly time series of $P, T W S A$, and $E T$; and (c) annual averages of $P, E T$, and $P-E T$. All time series data are spatially averaged over Zone 2 , and the phases are calculated based on the spatially averaged monthly variables of Zone 2 .

Figure 11. Plots of (a) phases between $E T$ and $P\left(\phi_{E T-P}^{Z \text { one }}{ }^{3}\right)$, and between $E T$ and $T W S A\left(\phi_{E T-T W S A}^{Z \text { one }}{ }^{3}\right.$; 
(b) monthly time series of $P, T W S A$, and $E T$; and (c) annual averages of $P, E T$, and $P-E T$. All time series data are spatially averaged over Zone 3 , and the phases are calculated based on the spatially averaged monthly variables of Zone 3 .
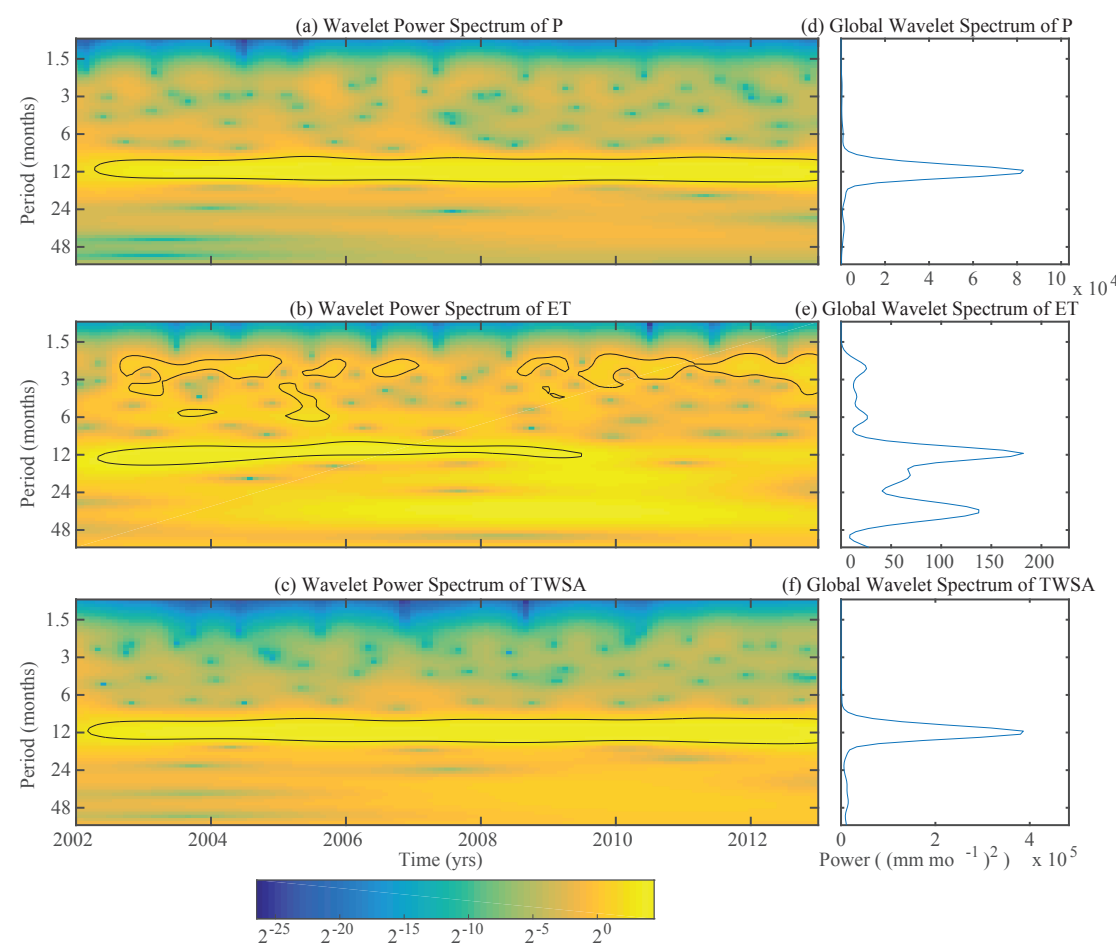

Figure 1. Contour plots of wavelet power spectra of precipitation (a), ET (b), and TWSA (c), and global wavelet spectra of precipitation (d), ET (e) and TWSA (f). The x-axes of subplots (a), (b), and (c) represent the time, the y-axis represents the periodicity scale, and the color represents the magnitude of the wavelet coefficient. The contour lines enclose regions of greater than $95 \%$ confidence (Torrence and Compo 1998). The $\mathrm{x}$-axes of subplots (d), (e), and (f) represent the power of global wavelet spectrum.

\section{Hosted file}

Figures-20200730.pdf available at https://authorea.com/users/348208/articles/473682-spatialand-temporal-variations-of-evapotranspiration-groundwater-and-precipitation-in-amazonia 